\title{
Ao redor do invisível: o tempo em suspensão no processo criativo de Cláudia Erança
}

\author{
Aparecido José Cirillo \\ Stela Maris Sanmartin
}

\section{Sobre Trânsitos, Quadraturas e Oposições}

A temporalidade de uma obra de arte não é da mesma ordem da cronologia do dia-a-dia... (Tunga) ${ }^{3}$

ESTE ARTIGO APRESENTA UMA INVESTIGAÇÃO SOBRE O PROCESSO DE CRIAÇÃO DA OBRA “Trabalho do Chão" (2019) da artista visual Cláudia França. Trata sobre a operacionalização e instauração da instalação que estabelece diálogo expandido entre o desenho e a escultura, procedimentos tradicionais que são incorporados e atualizados no trabalho. A análise integra um estudo amplo sobre criatividade e processo criativo dos artistas no Espírito Santo, composto por um conjunto de pesquisas financiadas pela FAPES, nas quais buscamos não apenas traçar uma história da arte em solo capixaba, mas principalmente compreender as nuances da mente criadora desses artistas.

Metodologicamente, neste texto partimos da hipótese de que Cláudia França recorta o espaço simbólico de seu vivido e o reconstrói como obra no tempo, como instante interrompido e congelado. Ao recriar um ambiente doméstico, ela propicia reflexões sobre as noções de paisagem, de arquitetura e sobre as relações humanas. Iniciamos essa interação com a mostra como espectadores, uma experiência sensível como participantes da obra; entrevistamos, posteriormente, a artista e adentramos também no estudo dos seus documentos de processo. Ao buscar traços de sua experiência como artista, nos deparamos com sua prática como astróloga amadora, sendo surpreendidos pelos modos como esse universo, paralelo à sua atuação como professora e artista, afeta o seu processo criativo. Assim, estabelecemos possíveis diálogos dessa sua ação na astrologia com o seu processo de trabalho como artista, buscando desvelar alguns aspectos geradores dessa obra.

Percebemos que essa informação paralela à produção artística (o campo da astrologia) se mostrou relevante para a análise desse processo criativo que tem no vivido da artista sua matéria edificante, ou para usar um termo de Salles (2008), a sua imagem geradora. Tomando um pouco do pensamento de Louis Hay, podemos afirmar que há uma “[...] passagem do vivido para o revivido, do revivido para o imaginário” ${ }^{4}$, na construção da

\footnotetext{
${ }^{1}$ Professor Doutor do Programa de Mestrado em Artes (PPGA/UFES) e do Programa de Mestrado em Comunicação (PPGCS/UFES), pesquisador FAPES e artista plástico. Contato: josecirillo@hotmail.com

2 Professora Doutora do Programa de Mestrado em Artes (PPGA/UFES) e pesquisadora FAPES. Contato: stelasanmartin@yahoo.com.br

${ }^{3}$ TUNGA. Tunga estabelece novas cadências no ritmo da arte: artista explica opção por levar à Documenta três "instaurações", obras com teor estático e dinâmico. [Entrevista concedida a Celso Fioravante]. Folha de São Paulo, São Paulo, Caderno Ilustrada, 17 de julho, 1997.

${ }^{4}$ HaY, Louis. A montante da escrita. Tradução de José Renato Câmara. Papéis Avulsos. Rio de Janeiro: Fundação Casa Rui Barbosa, n. 33, p. $5-19,1999$, p. 15.
} 
obra desta artista; deste modo, os documentos do processo criador de França parecem permear tanto o seu percurso de vida, quanto sua própria obra. São experiências sensíveis vivenciadas pelo corpo e mente do sujeito criador que vão sendo registradas ou reorganizadas como obras. No caso específico de recorte deste texto, a reoperação da experiência como astróloga parece ter uma materialização inquestionável de elementos formais no percurso gerador dessa instalação em estudo. Nesse caminho da análise, foi possível identificar as recorrências, as escolhas e as decisões que conduziram à execução da instalação apresentada ao público e finalmente pontuar questões críticas e poéticas que o trabalho parece suscitar e revelar.

Assim, numa analogia mais ampla com o universo dos astrólogos - no emaranhado de planetas, sujeitos, possibilidades e tempos - podemos pensar que os investigadores do processo de criação vão ao encontro de transformações que podem revelar, não apenas as tendências e intencionalidades prováveis da obra que se coloca aqui e agora, mas também traçar uma espécie de mapa de possibilidades que revelam associações e toda uma sorte de efemérides que permitam identificar recorrências do projeto poético de um artista, de sua assinatura pessoal, de um autor de modo geral. Como fazedores de mapas processuais, uma espécie de portulanos medievais, os pesquisadores do processo orientam-se pela experiência, identificam os pontos de acesso, são guiados pelos astros da intuição sobrepondo informações, cruzam variáveis, trançam tangências de um céu em movimento: cartografam o processo criativo; enfim, os críticos de processo tentam identificar portos de estabilidade no oceano da criação.

Assim, este estudo tem como meta compreender alguns desses trânsitos que perpassam o processo criativo de Cláudia França, uma mulher entre dois mundos, entre o da planaridade tradicional do desenho na irreverente volumetria incorrigível da escultura; e entre o mundo científico da Academia e seus conflitos com o universo esotérico da Astrologia. Em conjunção, entretanto, segue em seus mundos paralelos. E nessa conjunção, o melhor dos dois mundos é tomado pela artista, a energia envolvida trabalha em colaboração: revelam a influência de um mundo sobre o outro e demarcam o seu processo criativo. Quando esses fenômenos se opõem, parece que o fazem como complementos, como forças geradoras. Revelam um propósito, uma missão de vida no percurso poético dessa artista.

Tomamos como foco inicial de nossa reflexão, os elementos geradores que indiciam o futuro (a espera agostiniana da obra a ser apresentada). Indiciamos os rastros dos processos de criação, os vestígios que levam a forma, os elementos disparadores que se articulam, integram e compõem o trabalho artístico, mas não o fazemos apenas a partir somente de documentos autógrafos da obra. Entendemos que o meio (ambiente e cultura) também impregnam, nesse mapa do processo criativo, uma marca. Fundamentados no modelo sistêmico da criatividade $^{5}$, desconsideramos que a criatividade está restrita às mentes criativas, mas é a interação entre o pensamento e o contexto sociocultural no qual o criador está imerso, portanto, a criatividade tem uma matriz colaborativa, ou coletiva. Levaremos em conta os antecedentes, os contextos, as referências, as escolhas, as relações estabelecidas, aquilo que se pretendia e que na execução foi sendo deixado de lado e os elementos que não aparecem - ou não se explicitam - em um trabalho artístico. Elementos que, mesmo presentes, estão ocultos para a análise genética da estrutura e dinâmica do processo criativo, visto de diferentes pontos de vista.

Considerada a metáfora astrológica em França, hipotéticas linhas azuis, vermelhas, ora verdes de uma cartografia astral são convertidas em branco em seu mapa criativo; se cruzam nessa constelação que é o processo criativo desta artista, transformadas simplesmente em linhas que orbitam a obra em curso. O desejo desta

${ }^{5}$ Csikszentminalyi, Mihaly. Recreativity: flow and The Psychology of Discovery and Invention. New York: Happes Collins, 1996. 
escritura parte das primeiras impressões como espectadores participantes da obra "Trabalho do Chão", de 2019 (figura 1). No espaço expositivo da Galeria Homero Massena, levados pelo lançamento do catálogo, fomos tomados pela obra e conduzidos pelo desejo; nos colocamos a investigar os bastidores da instalação. O objeto no espaço da galeria, convocava à presença.

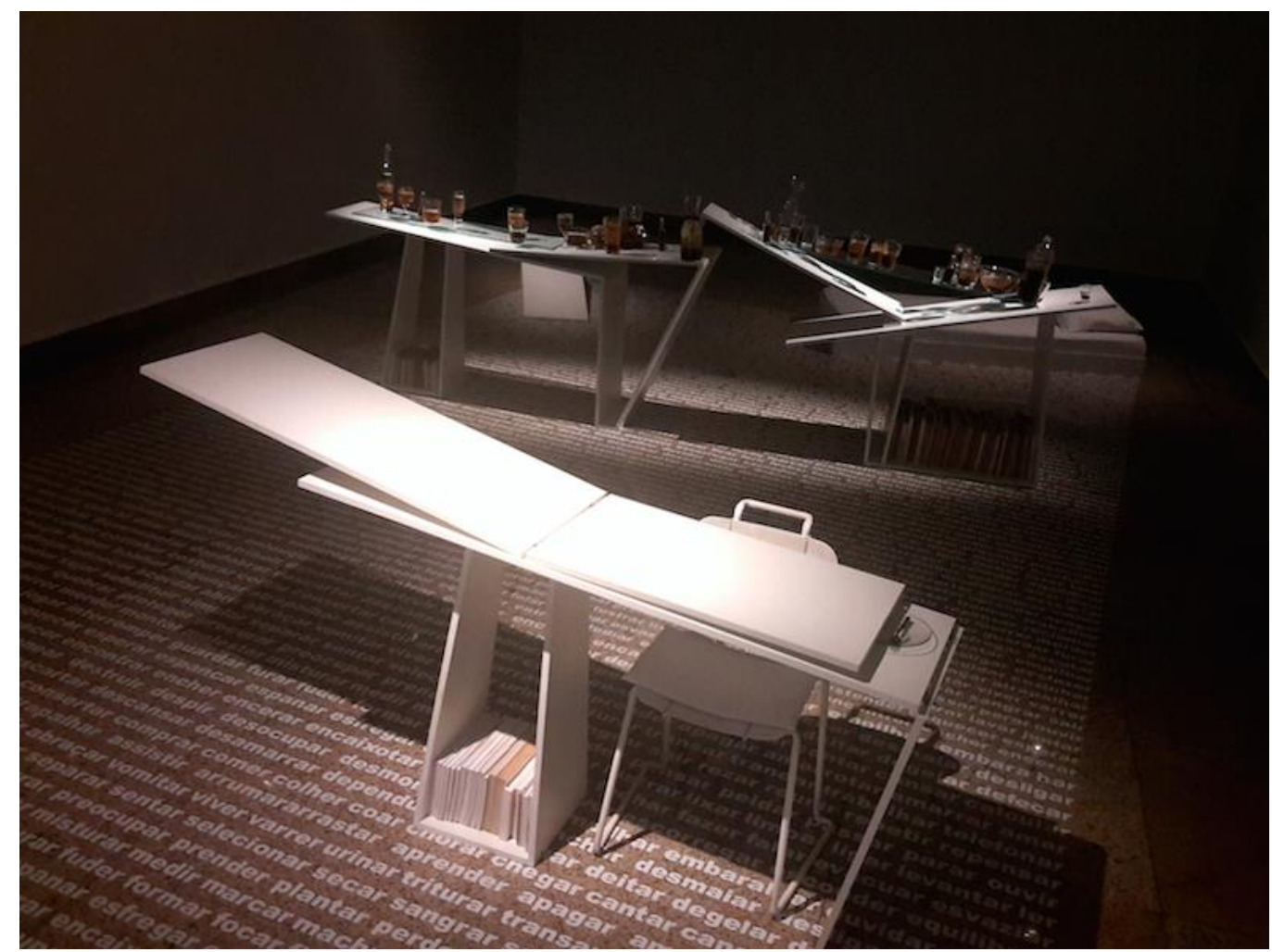

Figura 1: Cláudia França, Trabalho de Chão, Galeria Homero Massena, 2019. Fonte: acervo da artista.

A obra, no espaço expositivo, convocava para "entrar na casa", sob meia luz. A galeria com paredes inteiramente brancas, dirigia o olhar para o chão coberto por um tapete branco, habilmente tecido com palavras que se tornavam texto e textura. Segundo Guimarães, “[...] Esse texto só de verbos faz do chão uma gigantesca página, mas cujos sinais gráficos chegam primeiro ao visitante como textura”. ${ }^{6}$. Assim, o olhar como espectador, ainda tomado de sobressalto, se move para a linha do horizonte, onde justapõem-se planos. Linhas e planos que fazem alusão a mobiliários, mas, mantendo sua força como objeto autônomo (figura 2).

Três diferentes ambientes se desnudam à medida que o corpo observador caminha pelo espaço, sobre o tapete; o ambiente doméstico vai sendo revelado; denotam-se lugares diferentes para fazeres específicos. Na entrada um lugar para o trabalho; uma cozinha de alquimista; um leito para o descanso. Aparentemente, vai-se do mais público ao espaço mais íntimo. Construíam-se os alicerces das primeiras interpretações afetivas; as linhas brancas de verbos comandam a ação que ocupa a sala. Os astros se estruturavam naquele meio de céu: ${ }^{7}$

${ }^{6}$ GuIMARÃES, Lincoln. In: FrANÇA, Cláudia. Catálogo da exposição Trabalho do Chão. Vitória: Galeria Homero Massena, 2019, p.6.

${ }^{7}$ Embora usado aqui de modo metafórico, é preciso esclarecer que o termo "Meio do Céu" é um termo astrológico, significa o ponto mais alto do céu na representação da carta natal, a partir de seu horário de nascimento. O Meio do Céu (o MC) é o ponto de reconhecimento social de um indivíduo, sua imagem pública, como ele se insere socialmente por meio do trabalho e a relação adquirida. Ponto oposto ao MC é o Fundo do Céu (IC), a dimensão mais íntima de um indivíduo, as relações 
trabalho, leitura, estantes e livros, ao lugar intermediário da cozinha, laboratório de alquimia, imagens da transformação, corpos transparentes, frascos com terras e líquidos que parecem velar no lugar mais afastado, onde uma forma, cama vestida de roupa e travesseiro, revelava. Astrologicamente, estaria situado no Fundo do Céu o lugar subjetivo onde estão as memórias do sujeito (artista ou público). Tudo tomado por um manto de alvura. Branco, mas extremamente quente e silencioso. Tudo parecia tomar o espaço em suspensão. Habitado pelo que vem de longe. Nosso túmulo.

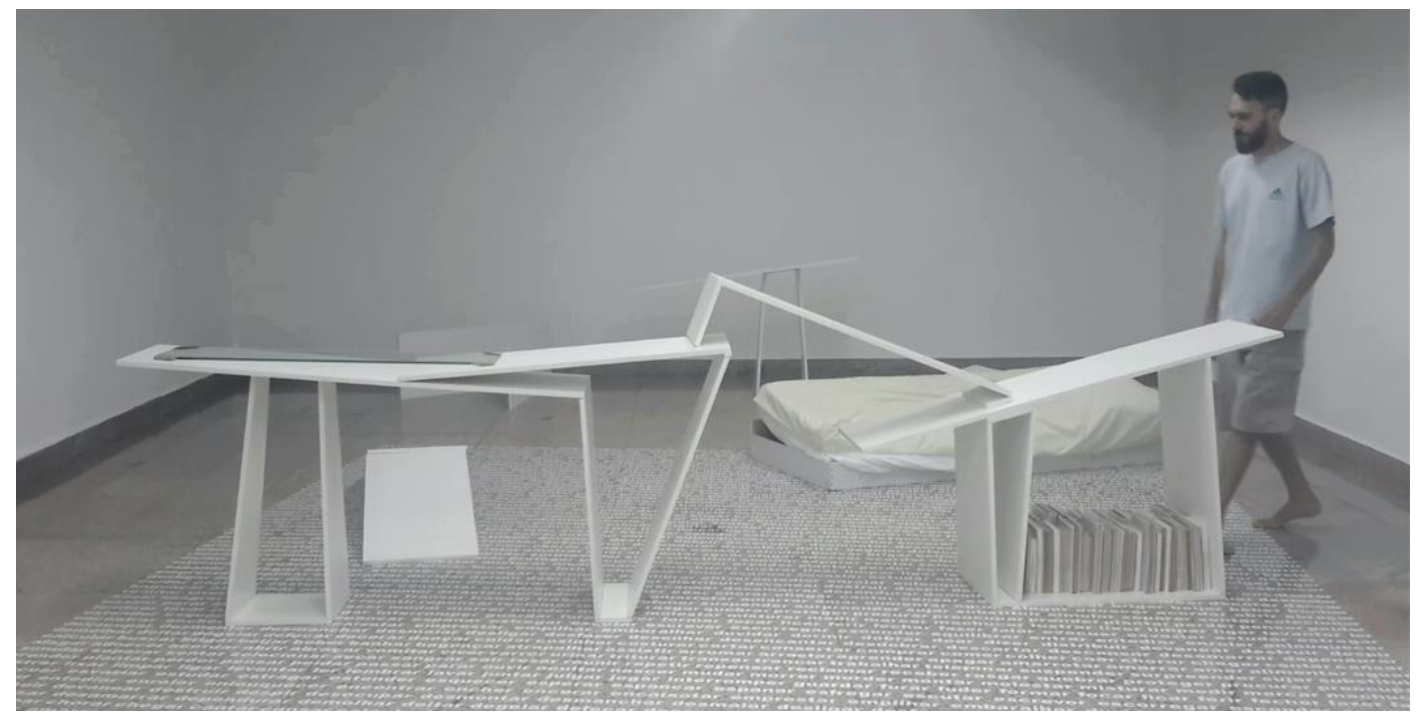

Figura 2: Cláudia França, Trabalho de Chão (2019). Detalhe da montagem. Fonte: acervo da artista.

A instalação parece apresentar-se como um trabalho autobiográfico empático que admite o outro, de modo que este outro também se reconheça nele ao reservar um intervalo de tempo para estar no "Trabalho do Chão". Mas, parece que este outro apenas olha pela janela. Ou por uma tela interativa que, qual em realidade aumentada, permite-lhe viver a emoção, mas não tocar os objetos. Como uma conjunção astral que se sabe estar lá, mas não se vê. Por trás daquela conjunção visual, uma conjunção de vida, obra e memórias da artista e do público interpostas e mediadas pela obra. Temporalidades sobrepostas que se evidenciam por meio do invisível.

\section{Sobre o tempo na obra: uma hipótese de suspensão}

Consideremos agora o que poderia surgir como existindo no instante presente se estivesse completamente separado do passado e do futuro. Só podemos adivinhar, pois nada é mais oculto do que o presente absoluto. (C.S. Peirce) ${ }^{8}$

Na obra "Trabalho do Chão" (2019), pode-se perceber uma clara tensão entre as linhas que se desenham e avolumam o/no espaço da galeria. Há tensão em cada objeto em sua suspensão; cada um tensionado

com a infância, suas memórias, a casa dos pais, a casa ideal, a sua casa atual como herdeira de um modo de habitar trazido de longe. Pode-se considerar que o Fundo do Céu é o nosso túmulo. Sendo assim, embora o centro espacial da instalação transite como "meio do céu", pode-se afirmar que o tema da instalação seja da ordem do Fundo do Céu.

${ }^{8}$ CIRILlo, Aparecido José. Imagem-lembrança: comunicação e memória no processo de criação. 2004. 161p. Tese (Doutorado em Comunicação e Semiótica). Pontifícia Universidade Católica de São Paulo, São Paulo, 2004, p.15. 
pela tangente de uma e de outra forma; são instantâneos congelados de objetos em tombo. Essa tensão se estende ainda no contraste do tapete branco com o piso de granito; sendo evidente também nas diagonais dos objetos em contraste com os vértices da galeria. A tensão como oposição primeira, incita. Incitar gera o movimento. $\mathrm{O}$ movimento é uma possibilidade de apreensão do tempo. Do tempo como extensão. Do tempo em suspensão. O trabalho parece se colocar como passagens do presente, nas quais os poderes primordiais nunca se detêm, pois, o ciclo do devir parece seguir o seu caminho, mesmo sem se interromper. Isso porque, entre os dois poderes primordiais (a linha e o plano), surge um contínuo estado de tensão, uma diferença de nível que os mantém em movimento, levando-os a se unirem. Com isso eles estão sempre gerando um ao outro, sem cessar. Os poucos momentos de alívio (como a cadeira) parecem ser mais dos momentos da pausa, da reflexão, do cansaço. O tempo parado pulsa na obra de França. Há uma clara intenção de provocar essa pausa no observador. Essa tensão fica evidente nos ângulos de suas linhas nos seus projetos da obra. Suas linhas são tensas. Levemente duras.

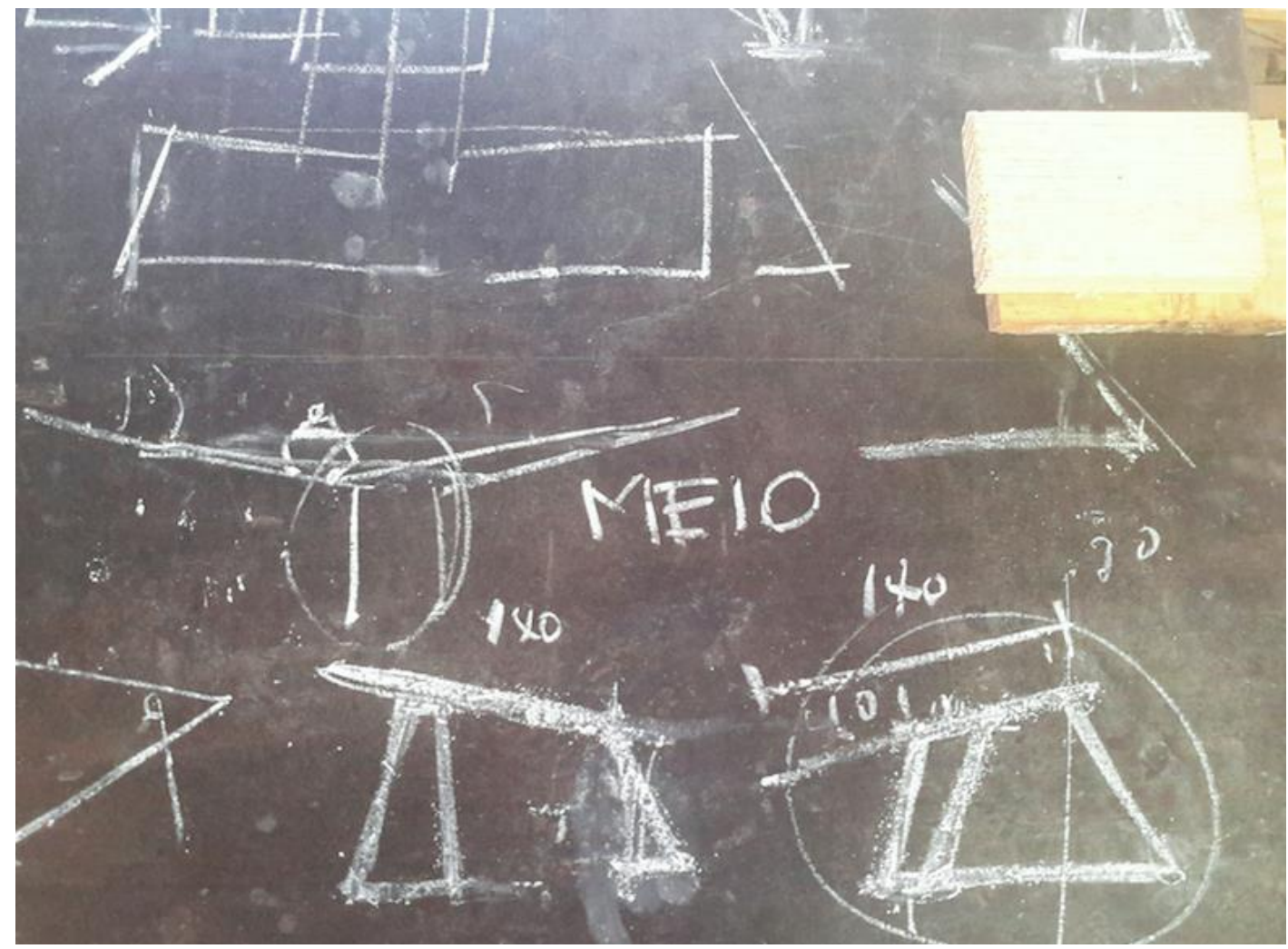

Figura 3: Cláudia França, Desenho na mesa da marcenaria. (2019). Fonte: acervo da artista.

Pulsação e tensão. Esse binômio da vida é a imagem do movimento, mas de um tempo tomado em suspensão. O mover-se do luminoso, da alvura que não toma a luz para si, do contrário, a reflete totalmente. Ofusca os olhos do percebedor (público). Esconde o que exposto não quer ser visto. Instaura o instável sobre o estável. Em sua imanência, esta suspensão é a própria imagem do movimento, tomado na (in)finitude de sua duração como presente que corre diante da visão. Um tempo agostiniano, repleto de esperas e de memórias. Através desta ação (aqui tão lenta que não se faz perceptível), Cláudia França parece conseguir reunir com facilidade o que está dividido. O céu astrológico que marca o nascimento dos sujeitos; e a vida que segue seu percurso olvidado que integra o universo. É na junção das forças primordiais da criação e da intimidade da artista que o movimento ganha direção determinada, ainda num estado germinal do vir-a-ser. Um lugar de conjunção e de ausências. 
Se tomamos um dos desenhos, estudo de processo criativo da obra (figura 3), podemos claramente perceber que sua imagem geradora parece devir dos seus mapas astrais. As linhas retas são diretas, curtas, interrompidas na tangência com a outra. As únicas linhas circulares são apenas indicativas de conjunções, não sendo estruturantes como as paralelas e diagonais apresentadas na obra. O que parece reforçar que já no processo criativo se revela uma intencionalidade tensiva entre as linhas e os pontos. As linhas, sempre retas, dão forma, tocam-se em ângulos: retos, agudos, obtusos... sempre numa lógica geométrica que remete aos mapas astrais com os quais a artista divide o seu tempo criador (figura 4).

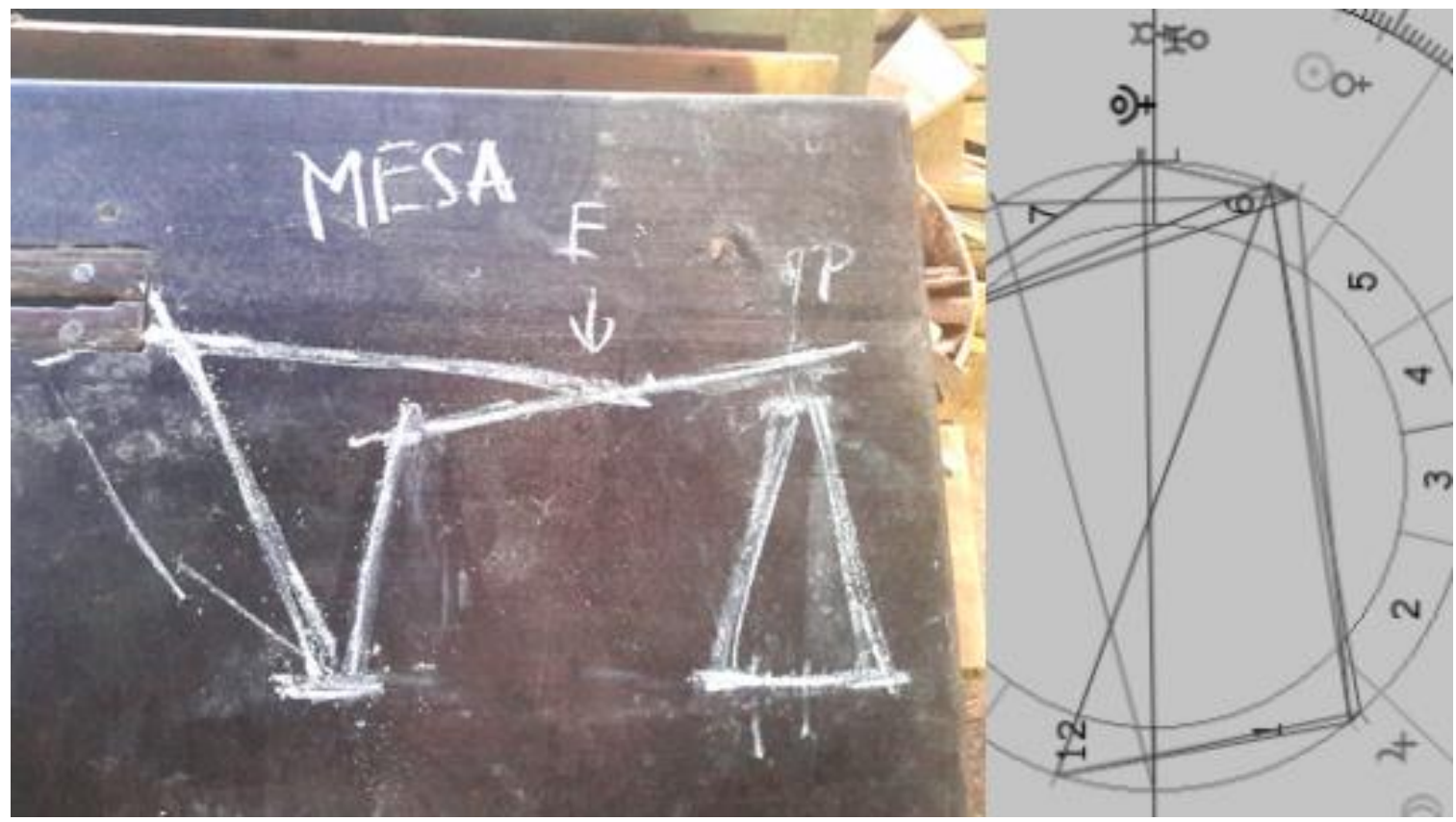

Figura 4: Desenho preliminar da obra "Trabalho de Chão" (2019) e detalhe de mapa astral.

Fonte: Banco de Dados do LEENA-UFES.

Pode-se perceber nessas imagens que há uma clara conexão entre os dois mundos nos quais a artista trafega: a dimensão estética e a dimensão astrológica. O diálogo não apenas da linha reta e suas tangências, mas a predominância da própria reta sobre os planos. Um olhar sobre o processo criativo de Cláudia França revela uma artista entre dois mundos.

Ao longo do estudo dos documentos de processo desta obra da artista, a leitura das marcas dialógicas de sua mente criadora revela essa tendência poética que transita nos dois mundos: o físico e o astrológico (o linear e o espacial). Mas, sobretudo, não podemos deixar de considerar elementos externos ao seu corpo que deixam marcas evidentes da influência do meio ambiente na sua produção. Seu recente deslocamento de Belo Horizonte/Uberlândia, no interior brasileiro, para Vitória, no litoral, evidencia o resultado de relações sistêmicas entre o domínio, regras simbólicas e procedimento, com a experiência vivida pela artista e o campo. As paisagens desses ambientes se configuram de modos distintos e isto parece acionar reflexões estéticas na artista. Novamente ela parece transitar entre dois mundos distintos de construção dos espaços: desde a sinuosidade das montanhas de Minas, para a angulosidade das montanhas capixabas. A artista, neste momento, parece tomada de uma força interna que revela ao ambiente mediado pela razão, ela reopera o aparentemente estático e estável da linha sinuosa em uma expressão sensível e tensa da linha reta. Esses pontos parecem índices do admirável na obra de Cláudia França. 
Em seu processo criativo para a obra "Trabalho do Chão", França parece transitar entre a planaridade tradicional do desenho e a volumetria incorrigivelmente sintética da sua escultura, porém uma escultura tão linear, quanto seu desenho. Essa conjunção também parece transitar no melhor dos dois mundos, e a energia envolvida nessa tensão da linha e do plano trabalha em colaboração, revelando a influência de um mundo sobre o outro, se complementam. Podemos afirmar que nesta conjunção de mundos se estruturam as imagens geradoras e estruturantes da obra "Trabalho do Chão". Novamente, nos parece aqui uma indicação da influência de seu trabalho como astróloga e como artista.

Esses índices permitem o acesso às dúvidas, experimentações, deslumbramentos, decisões e reflexões sobre a obra, sobre a arte e sobre a própria identidade psicossocial da artista, buscada em muitas das suas vivências tomadas em suspensão na obra. Podemos dizer que "Trabalho do Chão", nasce do chão no espaço da galeria. O Tapete de palavras (figura 5), que não aparece em nenhum dos rascunhos disponibilizados para estudo, revela um processo em ação. Ocorre como ideia e se materializa na montagem. São verbos de ação. Um tapete branco tecido de palavras. Habilmente, de palavras torna-se também textura. Estruturas que alinharão o olhar à linha do horizonte por meio de um conjunto de planos justapostos.

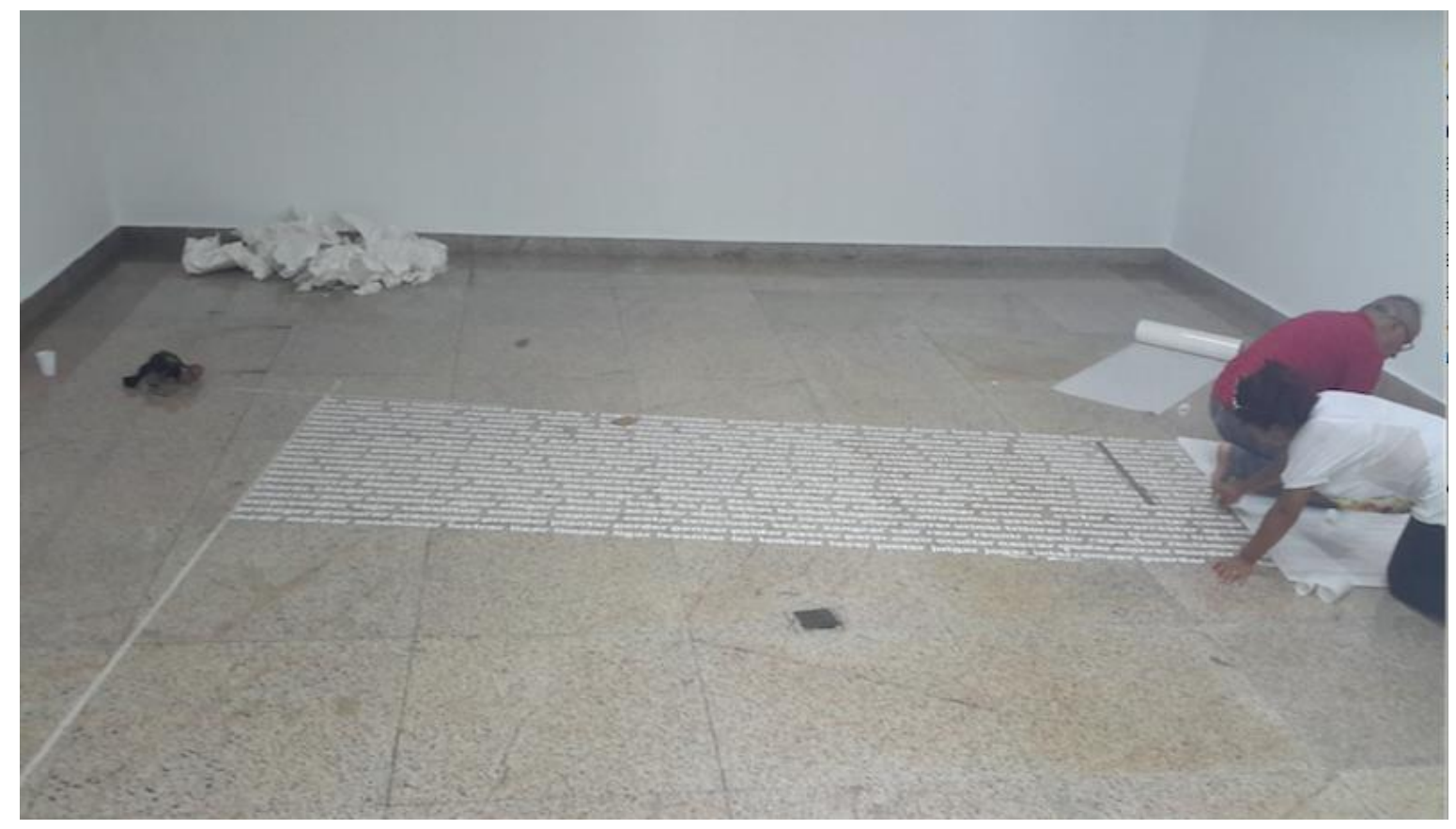

Figura 5: Detalhe da montagem do tapete de palavras de "Trabalho de Chão" (2019).

Fonte: acervo da artista, Banco de Dados do LEENA-UFES.

Em entrevista aos autores, França afirma que cada parte do espaço tem sua voz e que procurou escutar o chão e colocá-lo para trabalhar com ela. Assim, a partir do chão ela vai edificando o espaço da obra. Embora orientada por uma maquete (figura 6), é no embate dialógico com o espaço que ela vai construindo esse espaço em suspensão que é a obra. Mesmo na maquete, verificamos que o verbo se antecipa ao objeto visual. 


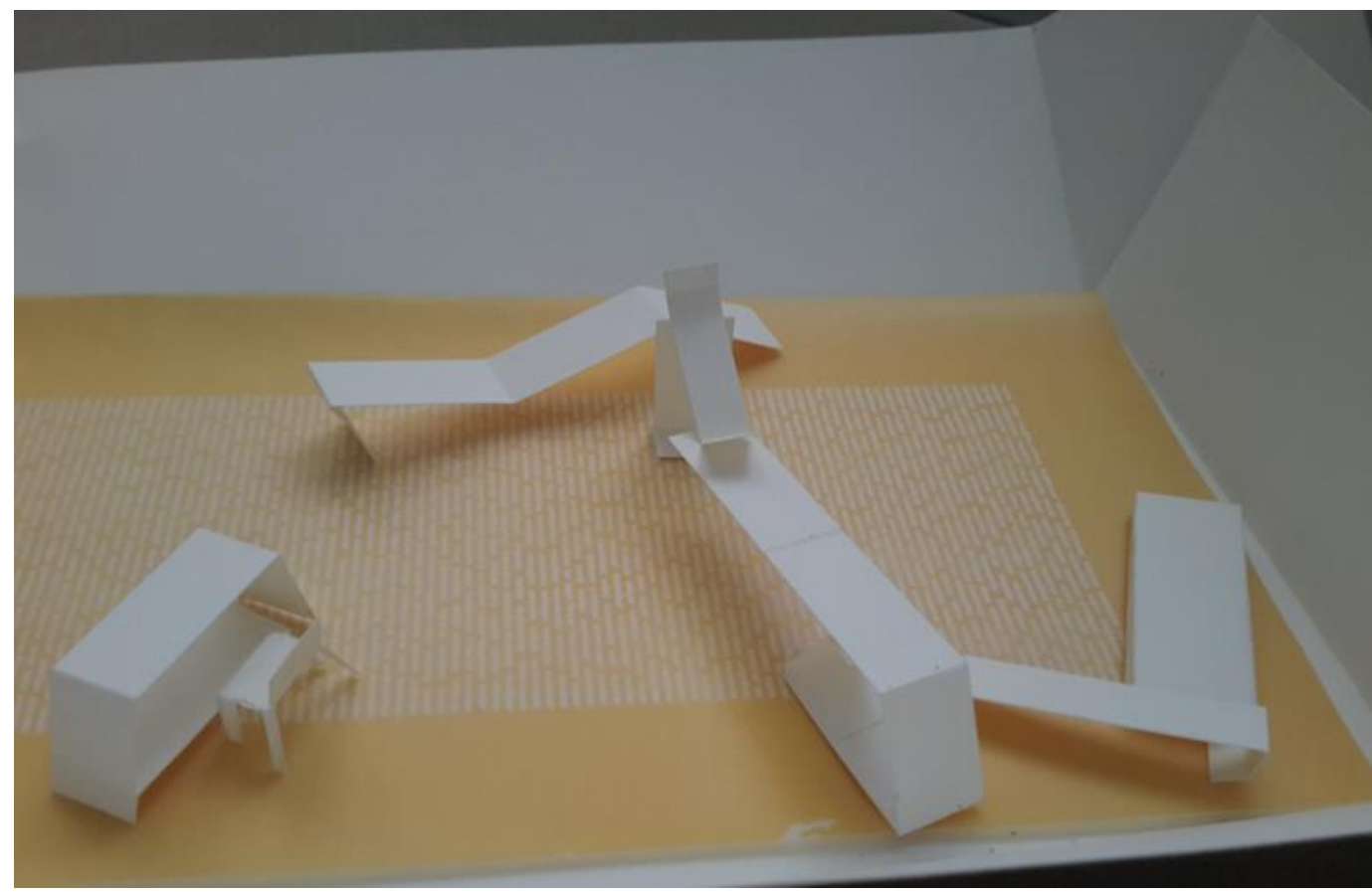

Figura 6: Maquete da obra "Trabalho de Chão" (2019). Papel recortado e caneta.

Fonte: acervo da artista, Banco de Dados do LEENA-UFES.

Como já anunciado na maquete, o espaço vai se estruturar em diferentes ambientes que se desnudam ao corpo do observador à medida que este caminha pelo espaço sobre o tapete. Neste percurso acontece a obra, sua mediação com o espaço e com os sujeitos. A intimidade da artista parece revelada ao se percorrer o espaço da galeria ao longo da obra. Mas, a obra proposta ao público não se dá de imediato, exige um percurso e uma contemplação. Uma ação de mover-se pelo espaço. A obra toma o espaço como matéria, suas paredes, seu chão, sua linha do horizonte demarcada pelo rodapé da sala. Sua iluminação dá volume aos objetos. É de fato uma instalação.

Podemos considerar que uma instalação é a arte do espaço, mas filha do tempo, pois reconhece o espectador em trânsito. Os espaços articulados favorecem a narração, a percepção de uma parte ou outra e requer que o espectador, ao se deslocar, faça a ligação. A análise do processo criativo dessa obra de Cláudia França nos faz pensar que ela se constrói em uma metáfora da suspensão.

\section{Ao redor do invisível: a casa reinventada}

Arte e vida, como dimensões que se confundem na rotina do dia a dia da casaateliê ${ }^{9}$. Cláudia França fez a opção de não dividir os espaços de trabalho, não se distanciar, mas vivenciar movimentos de sístoles e diástoles para convergi-los nas efemérides, nas diferentes perspectivas de ação. Processos intervalados entre fechamentos e aberturas, ritmados entre tensão e distensão, problema e resolução. Momentos essenciais do viver e do fazer arte em processos que oscilam ora para momentos conscientes, ora inconscientes, intuitivos.

\footnotetext{
${ }^{9}$ Em entrevista com os autores, Cláudia França deixou claro que não tem um espaço de casa e um espaço de ateliê separados, sua casa é o ateliê e obras em processo se espalham criando um "casaateliê", nas palavras da entrevistada. Assim, o seu cotidiano de artista coabita seu tempo como professora e suas ações como astróloga. Existências de um mesmo ser que coabitam seu espaço de vida e sua própria existência como sujeito.
} 
Assim, num projeto poético centrado em experiências do corpo transformadas em imagens visuais, falar em processos intuitivos no procedimento criativo de França é quase uma redundância, porque o seu vivido, aparente matriz da sua obra, é repleto de imprevistos que imponderavelmente desviam o curso natural da existência da obra, mas a artista intuitivamente os alinha. Resta-lhe acatar o acaso e desviar temporariamente a rota da criação e, assim, constituir um novo percurso criativo seguindo seu instinto - tão caro também na astrologia. Podemos afirmar que a intuição ${ }^{10}$ agrega ao processo de criação informações que seriam inacessíveis de outra maneira; recebe informações do ambiente que não são evidentes aos sentidos ou a mente racional, da mesma maneira catalisa o material ativado inconscientemente por meio de sensações, impressões e imagens. Por meio da intuição, há impulsos e sugestões de caminhos a seguir; e, enquanto a percepção consciente apreende do mundo exterior os elementos sensíveis, o ambiente estético nutre o repertório para as escolhas e para as decisões. As diferentes ações mentais (seguir o impulso, domar o vivido, pensar o acervo de si, etc.) refletem uma tendência criativa de mediar as tensões do processo em direção ao produto a ser entregue.

No caso de França, nos parece que este conflito é dialógico e não antagônico. Os opostos se complementam e geram a ação criadora. A tensão dos mundos - doméstico, estético e de trabalho - desencadeia o movimento de busca e provoca a abertura para olhar, para o capturar e para o nutrir-se com os elementos do cotidiano, encharcados da recolha sensível do outro tempo que se instaura: o recolhimento, a introspecção para que os insights venham à tona e iluminem o caminho a ser perseguido para elaboração do trabalho. Intuição e razão em diálogo para realizar, executar o ideado. A obra apresentada vai tomando para si esses elementos; os reorganiza como em uma sinfonia.

Musicalidade do silêncio, espaço silencioso, paredes brancas, paisagem na linha do horizonte e verbos de ação no tapete de palavras. Testemunho do trabalho na casa, agora reconstruída, reinventada. Ao comentar com os autores sobre o título do trabalho, a artista diz que cada parte do espaço tem sua voz e procurou escutar o chão e o colocou para trabalhar com ela. A instalação é a arte do espaço, mas implica o tempo ao reconhecer o espectador em trânsito, tal qual os astros no céu da carta astrológica. "Trabalho do Chão" parece dizer sobre os estados do viver sem chão fixo. Das transitoriedades, dos deslocamentos, sobre as instabilidades, mobilidade da casa nômade.

A instalação "Trabalho do Chão" instaura uma situação com objetos que, ao serem desmanchados, retornam para seus papéis ordinários. Os objetos da casa ora são da casa, ora são da obra alterando sua hierarquia e funções; mas sempre são linhas, quase planos que se elevam das linhas/plano do texto verbal no chão. Objetos autorrepresentacionais que desnudam a artista em uma vertente autobiográfica. Coleções de louça, livros e mobiliário que a artista se utiliza para criar as situações instalativas que testemunham histórias e acumulam camadas de memória (da artista, do espaço, do público, dos objetos, etc.) ao vestir o espaço de carga afetiva e simbólica que carregam. São camadas de tempo compartilhados na forma metafórica de casa. A casa é tema e lugar desse trabalho. Trabalho de casa e de arte que incorpora a ludicidade da invenção. A obra parece trazer esse tempo de casa para a galeria, mas o faz congelando o tempo. São eternas memórias, imagens-lembranças impregnadas como arquétipos impressos na memória e materializados em obra no processo de França. A forma do vivido gravado na memória não se coloca como passado, ou como algo que se põe no lugar da experiência sensível: como memória, ela é experiência em ato. A imagem, tornada lembrança, transforma-se novamente em imagem e esta se torna, então, uma imagem-lembrança ${ }^{11}$.

Em França, essas imagens-lembranças são tratadas como arquétipos - como na astrologia. Arquétipos como imagens primordiais e universais. A dimensão arquetípica do símbolo, tratado como imagens herdadas do

\footnotetext{
${ }^{10}$ Ver mais em ABRANTES, Ana; SANMARTIN, Stela Maris. Intuição e criatividade na tomada de decisões. São Paulo: Trevisan Editora, 2017.

${ }^{11}$ CIRILLO, op.cit., p. 126.
} 
seu passado ancestral para entender o funcionamento presente de $\mathrm{si}^{12}$, se dá na transcendência da perspectiva individual e alcança o coletivo, assim os sujeitos acessam e experimentam conteúdos similares e os ressignificam a partir de seu repertório, advindo de suas experiências e história subjetiva. A obra parece ser a materialização da experiência vivida, que é transformada em uma imagem-recordação ${ }^{13}$ acessível pela mente criadora de cada sujeito (seja o artista, seja o público), e essa imagem-recordação do objeto, como lembrança, está impressa na memória ${ }^{14}$. Desse modo, são estratégias de conservação que facilitam à experimentação criadora transformar a experiência sensível em imagens geradoras e, como tal, encontrar mediações que acionam camadas temporais e memoriais dos objetos e dos sujeitos.

Para Bergson (1999), a lembrança é o objeto impresso na memória, e essa impressão se dá por meio da representação da forma, objeto ou experiência. A lembrança da forma é dada em uma relação de familiaridade com a forma: para isso é preciso que ela tenha as características de hábito; “[...] como hábito ela é adquirida pela repetição de um mesmo esforço" ${ }^{\text {"15 }}$. Mas, essa apreensão por hábito ainda é memória mecânica, adverte o autor. No processo de criação, é preciso que a mente criadora atue sobre a memória mecânica, de modo a sucedê-la por um movimento que transcenda o hábito. Estabelece-se um processo de revisão da imagem da forma original, de modo que ela é acrescida de algo mais que não lhe altera a natureza, mas que a põe em movimento no tempo, tornando único e particular cada momento nesse devir. Exatamente neste ponto, nos parece centrar-se a força do trabalho de Cláudia França: ela não apenas repete o hábito da forma grafada como memória, ela as ressignifica e reopera como arte. São linhas, planos e volumes que deixam de existir em sua função primordial no mundo das coisas e passam a ocupar o mundo sensível como acionadores de experiência sensível compartilhada. São trilhas pela memória cultural que nos une a todos.

Cláudia França parece acionar uma imagem-lembrança, em si e no público, por meio de formas, objetos e palavras que se estruturam como espécie de arquétipos que atravessam os tempos e os lugares. A artista suspende a experiência do vivido à medida que abstrai a ideia de representação da casa e aciona a apresentação, não mimética, de uma experiência simbólica com o conceito de intimidade do lar. Não a do seu lar, mas de uma morada do espírito humano. O projeto poético da obra parece acionar memórias a partir de formas impressas na percepção do público. A forma impressa na memória (do público, neste caso) não se coloca como passado, ou como algo que se põe no lugar da experiência vivida: como memória, ela é experiência em ato. A imagem, tornada lembrança, transforma-se novamente em imagem e esta se torna, então, uma imagem-lembrança.

\section{Considerações finais}

Esse breve estudo do processo criativo da obra de Cláudia França revela que os documentos de processo se estendem para além da materialidade dos documentos tradicionais (rascunhos, arquivos fotográficos, maquetes, arquivos digitais, dentre outros). Verificamos que condições externas ao sujeito criador (sua cultura e seu ambiente) se colocam como fenômenos sensíveis que são acionados pela mente criadora em sua complexidade no ato criador. O ambiente externo funciona como um autor externo ao sujeito da criação. Ele se

\footnotetext{
${ }^{12}$ Maiores informações sobre arquétipos e símbolos como herança ancestral (da cultura) para se compreender a si mesmo podem ser vistos em JunG, Carl G. O homem e seus símbolos. Rio de Janeiro: Nova Fronteira, 1964.

${ }^{13}$ Colombo, Fausto. Os Arquivos Imperfeitos. Tradução de Beatriz Borges. São Paulo: Perspectiva,1991.

${ }^{14}$ Bergson, Henri. Matéria e memória. 2. ed. Tradução de Paulo Neves. São Paulo: Martins Fontes,1999.

${ }^{15}$ Ibidem, p.86.
} 
configura como memória coletiva compartilhada não apenas pelo autor, mas também pelo receptor. Assim, as imagens-lembranças propostas pela artista não são miméticas ou do campo da representação. Essas imagens acionam o movimento. O movimento é ação que permite apreender o tempo.

Pode-se definir a ação poética como uma grafia de acontecimentos na vida, que são sitiados, situados e datados de modo a funcionar não apenas como armazenamento do passado, o que seria uma necessidade natural $^{16}$, mas como arquétipos que entrecruzam as temporalidades, edificando uma forma ao redor do invisível vivido pelo inconsciente coletivo. Como o acesso constante lhe é inerente, essas imagens-lembranças têm sua ação no tempo e no espaço contínuo da existência, permitindo a busca e a reoperação da experiência vivenciada (tanto pelo artista, quanto pelo público). Desse modo, seu tempo existencial é uma modalidade de presente: a suspensão. Atua determinando percursos e decisões da mente criadora; memória e espera se movendo na modalidade da visão que se põe nesse tempo agostiniano. Como em suas cartas astrológicas, o processo criativo de França tem essa tendência para falar de um tempo na ordem sideral; particular na medida que se entende como herança coletiva, para além da ordem temporal humana. Ele, o tempo da criação/percepção, é acionado para entender o momento, mas não se dá no momento. O momento, aliás, é um mero fragmento deste tempo sideral no qual se insere a obra e sua percepção/recepção. A carta astrológica, ou o rascunho da obra, acionam essa recorrência nodal do tempo para apropriar-se de sua capacidade de acionar outras memórias e promover compartilhamentos vivenciais por meio da obra exposta.

Assim, a artista parece se aproximar dessa tendência temporal, a qual Santo Agostinho chamou de passagem do presente ${ }^{17}$, que se difere do presente pontual por estender-se num certo espaço de tempo que torna possível a medida e apreensão do movimento, porque este - como o tempo - se dá em extensão. Nessa passagem pelo presente, ela, a obra, encontra no "tempo passado", reminiscências que revelam parte da fonte geradora de sua experiência formal e espacial. Na obra "Trabalho do Chão", Cláudia França instaura sua casaateliê, uma casa nômade que acolhe o outro como se também sua fosse aquela morada. Um deslocamento no espaço que nos leva a diferentes tempos, do passado ao futuro, e sincronicamente ao tempo suspenso da experiência estética. No silêncio da galeria, a musicalidade das imagens-lembranças é acionada pela mente de cada espectador participante que penetra e percorre este espaço inventado ludicamente. A instalação, também nômade, tem um tempo de existência determinado no espaço expositivo, mas indeterminado na memória de quem pode viver esta experiência.

A observação dos documentos de processo autógrafos ou aqueles de ordens coletivas e culturais formam uma documentação ímpar que permite compreender aspectos da experiência de recepção. O percebido pelo público na obra "Trabalho de Chão" parece nos revelar como o vivido pode ser entendido como matéria geradora do processo de criação e de recepção da obra. Cada uma das formas que constituem essa instalação parece anotações de uma experiência vivida; são imagens que se constituem como instrumentos de rememoração do vivido (pessoal e coletivo). Imagens-lembranças que acionam insights da dimensão compartilhada dos objetos que constituem nossa cultura e que permitem a assimilação e o compartilhamento das experiências visuais da arte.

Foi também possível perceber que a questão da presença do vivido, como matéria geradora da obra de França, é uma tendência revelada de seu processo criativo. Seu espaço de criação parece fazer a mediação entre a lembrança e a imaginação; aquilo que foi construído pela imaginação criadora da artista é tomado de seu vivido grafado em sua memória, constituindo-se como matéria edificante de sua obra. No caso dessa obra, podemos ainda salientar que, por sua natureza como instalação, cada possível remontagem implica em novas mediações entre a memória da artista e a do novo espaço, com suas matrizes existenciais e com a experiências dos sujeitos

\footnotetext{
${ }^{16}$ Ibidem.

${ }^{17}$ Santo Agostinho. Confissões. 11. ed. Tradução de Oliveira Santos e Ambrósio de Pina. Petrópolis: Vozes, 1992, pp. 266-296.
} 
participantes. Assim, como no mapa astral, mesmo nascido do mesmo corpo genético, no mesmo ano, as confluências específicas, as efemérides, redesenham o objeto apresentado e os modos como ele é percebido, num eterno redesenho do invisível.

\section{Referencias bibliográficas}

ABRANTES, Ana; SANMARTIN, Stela Maris. Intuição e criatividade na tomada de decisões. São Paulo: Trevisan Editora, 2017.

Bergson, Henri. Matéria e memória. 2. ed. Tradução de Paulo Neves. São Paulo: Martins Fontes, 1999.

CIRILLO, Aparecido José. Imagem-lembrança:comunicação e memória no processo de criação. 2004. 161p. Tese (Doutorado em Comunicação e Semiótica). Pontifícia Universidade Católica de São Paulo, São Paulo, 2004.

Colombo, Fausto. Os Arquivos Imperfeitos. Tradução de Beatriz Borges. São Paulo: Perspectiva, 1991.

CsiksZentminalYI, Mihaly. Recreativity: flow and The Psychology of Discovery and Invention. New York: Happes Collins, 1996, 456 p.

FRANÇA, Cláudia. Catálogo da exposição Trabalho do Chão. Vitória: Galeria Homero Massena, 2019.

GUIMARÃES, Lincoln. In: FRANÇA, Cláudia. Catálogo da exposição Trabalho do Chão. Vitória: Galeria Homero Massena, 2019.

HaY, Louis. A montante da escrita. Tradução de José Renato Câmara. Papéis Avulsos. Rio de Janeiro: Fundação Casa Rui Barbosa, n. 33, p. 5 -19, 1999.

JunG, Carl G. O homem e seus símbolos. Rio de Janeiro: Nova Fronteira, 1964.

SALLES, Cecília Almeida. O gesto inacabado. São Paulo: Anna Blume, 1998.

Santo Agostinho. Confissões. 11. ed. Tradução de Oliveira Santos e Ambrósio de Pina. Petrópolis: Vozes, 1992, pp. 266-296.

TUNGA. Tunga estabelece novas cadências no ritmo da arte: artista explica opção por levar à Documenta três "instaurações", obras com teor estático e dinâmico. [Entrevista concedida a Celso Fioravante]. Folha de São Paulo, São Paulo, Caderno Ilustrada, 17 de julho, 1997. 